\title{
Breast Cancer and Immune Thrombocytopenic Purpura: Is there any Association between these 2 Distinct Diseases?
}

\author{
Rasim Gencosmanoglua Pemra Unalan ${ }^{\mathrm{b}}$ Gozde Kir ${ }^{\mathrm{c}}$ Resit Inceoglu ${ }^{\mathrm{a}}$ \\ ${ }^{a}$ Department of General Surgery, \\ ${ }^{b}$ Department of Family Medicine, Marmara University School of Medicine, \\ ${ }^{\mathrm{c}}$ Department of Pathology, Umraniye Teaching Hospital, Istanbul, Turkey
}

\section{Key Words}

Breast cancer - Immune thrombocytopenic purpura .

Platelet · Thrombocytopenia - Immunoglobulin infusion .

Splenectomy

\section{Summary}

Background: An association between breast cancer and immune thrombocytopenic purpura (ITP) is very rare; there are only 18 cases reported in the English literature so far. Patients and Methods: A 65-year-old woman who had been diagnosed with ITP 5 years ago presented with 2 palpable masses in her left breast. Following establishment of the histopathologic diagnosis of invasive ductal carcinoma by fine needle aspiration biopsy, the patient underwent left modified radical mastectomy. Results: Histopathologic examination confirmed invasive ductal carcinoma in the bigger mass, and in situ ductal carcinoma in the smaller. The case was $\mathrm{T}_{2} \mathrm{~N}_{0} \mathrm{M}_{0}$, therefore exclusive anti-estrogen therapy was started for the next 5 years. However, thrombocytopenia recurred twice in the first postoperative year. Fluorodeoxyglucose positron emission tomography (FDG-PET) scanning showed no breast cancer metastases anywhere in the body. Following immunoglobulin infusion, the platelet count increased enough for surgery, and the patient underwent splenectomy for ITP in the 10th month after the previous breast cancer surgery. After an uneventful postoperative period, the patient has been symptom-free during the 1year of follow-up with normal platelet levels. Conclusion: Although the relevant current data are conflicting, in the present case no direct relationship between ITP and breast cancer could be observed clinically.

\author{
Schlüsselwörter \\ Brustkrebs · Immunthrombozytopenische Purpura . \\ Thrombozyt - Thrombozytopenie - Immunglobulininfusion . \\ Splenektomie
}

\section{Zusammenfassung}

Hintergrund: Zwischen Brustkrebs und Immunthrombozytopenischer Purpura (ITP) besteht nur selten ein Zusammenhang; in der englischsprachigen Literatur sind bisher nur 18 Fälle erwähnt. Patienten und Methoden: Eine 65-jährige Frau, bei der 5 Jahre zuvor ITP diagnostiziert worden war, wurde mit 2 tastbaren Umfangsvermehrungen in der linken Brust vorstellig. Die histologische Untersuchung der per Feinnadelpunktion entnommenen Biopsie ergab ein invasives Duktalkarzinom, woraufhin eine modifizierte Radikalmastektomie der linken Brust durchgeführt wurde. Ergebnisse: Die histopathologische Untersuchung bestätigte ein invasives Duktalkarzinom für den größeren Tumor, während es sich bei der kleineren Umfangsvermehrung um ein Duktalkarzinom in situ handelte. Die Patientin wurde als $\mathrm{T}_{2} \mathrm{~N}_{0} \mathrm{M}_{0}$ klassifiziert, woraufhin eine ausschließliche Antiöstrogentherapie über die nächsten 5 Jahre begonnen wurde. Innerhalb des ersten Jahres nach erfolgter Operation kam es jedoch zweimal zu erneuter Thrombozytopenie. Fluordeoxyglukose-Positronenemissionstomographie (FDG-PET) zeigte keine Brustkrebsmetastasen im gesamten Körper. Mittels Immunoglobulininfusion konnte die Thrombozytenzahl soweit erhöht werden, dass im zehnten Monat nach Brustkrebsoperation eine Splenektomie zur Behandlung der ITP durchgeführt werden konnte. Es traten keine postoperativen Komplikationen auf, und während des einjährigen Followups war die Patientin symptomfrei mit normalem Thrombozytenspiegel. Schlussfolgerung: Trotz der Widersprüchlichkeit der relevanten Daten konnte im vorleigenden Fall kein direkter klinischer Zusammenhang zwischen ITP und Brustkrebs hergestellt werden.

\begin{tabular}{ll}
\hline KARGER & @ 2007 S. Karger GmbH, Freiburg \\
Fax +497614520714 & Accessible online at: \\
$\begin{array}{l}\text { E-mail Information@Karger.de } \\
\text { www.karger.com }\end{array}$ & www.karger.com/brc
\end{tabular}




\section{Introduction}

Thrombocytopenia may occur in cancer patients due to several reasons during the course of the disease. Bone marrow hypoplasia secondary to chemotherapy and/or radiotherapy, bone marrow replacement by metastatic tumor cells, platelet consumption due to activation of the coagulation cascade, and development of thrombotic thrombocytopenic purpura (TTP) are the most common mechanisms [1]. On the other hand, immune thrombocytopenic purpura (ITP), an autoimmune disease in which the presence of auto-antibodies against platelets results in splenic sequestration and thrombocytopenia, may be associated with lymphoid neoplasms, particularly with chronic lymphoid leukemia [2]. However, the co-existence of ITP and solid organ tumors, including breast cancer, is very rare. The estimated incidence of ITP has been reported as 1 in 10,000 people among the general population [3]. On the other hand, breast cancer is the most common tumor in women; their lifetime risk of developing breast cancer is $11 \%$ [4]. It is still unknown whether the association between tumor and ITP is coincidental, or whether in such cases ITP is the result of cancer due to some unknown mechanisms. To the best of our knowledge, this report represents the 19th case of ITP in association with breast cancer in the English literature.

\section{Case Report}

A 65-year-old woman presented with a palpable mass in her left breast. She had been diagnosed with ITP 5 years ago. There was no underlying systemic disease that might result in increased peripheral destruction or decreased production of platelets. The patient was not under any long- term medication which might induce thrombocytopenia. Standard coagulation parameters were within normal limits, and the results of serologic tests for hepatitis B and C, cytomegalovirus, Epstein Barr virus, and human immunodeficiency virus were negative. Lupus anticoagulant test, rheumatoid factor, and antinuclear antibody were also negative. Besides, no evidence of other infectious diseases (involving the gastrointestinal tract, respiratory tract) that could have contributed to a decreased platelet count was detected. 4 episodes of severe thrombocytopenia (blood platelet count $<10,000 / \mathrm{ml}$ ) developed within the 5 -year period after the diagnosis of ITP, and the patient needed steroid therapy for each episode. She received a daily dose of $1 \mathrm{mg} / \mathrm{kg}$ oral methylprednisolone (Prednol ${ }^{\circledR}$, Mustafa Nevzat, Istanbul, Turkey), and an immediate satisfactory response was achieved each time. After a 30-day course, systemic steroids were discontinued by tapering $4 \mathrm{mg}$ every 5 days. On physical examination, there was a painless round mass, $2 \mathrm{~cm}$ in diameter, in the upper-outer quadrant of the left breast without any accompanying palpable axillary lymph node. Mammography showed 2 distinct masses with calcification, 1 and $2 \mathrm{~cm}$ in diameter, in the upper-outer quadrant of the left breast, and fine needle aspiration biopsies of both lesions revealed an invasive ductal carcinoma for the bigger one. Because the blood platelet count was low $(34,000 / \mathrm{ml})$ in the preoperative period, the patient received a subsequent steroid therapy with methylprednisolone at a dose of $1 \mathrm{mg} / \mathrm{kg} / \mathrm{day}$. Once the platelet count was within normal limits, the patient underwent left modified radical mastectomy. Histopathologic examination confirmed invasive ductal carcinoma in the bigger mass, and in situ ductal carcinoma in the smaller. The tumor had mild positivity (20-30\% of the tumor cell) for estrogen receptors, but was negative for progesterone receptors and erbB-2. Because the case was staged as $\mathrm{T}_{2} \mathrm{~N}_{0} \mathrm{M}_{0}$ in relation to the breast cancer, exclusive anti-estrogen therapy (tamoxifen $20 \mathrm{mg} /$ day) was started for the next 5 years. After an uneventful postoperative period, the steroid therapy was gradually decreased and eventually stopped within the next 2 months. However, thrombocytopenia (blood platelet count $<1,000 / \mathrm{ml}$ ) recurred 2 months later (fig. 1). If there was a relationship between ITP and breast cancer, the presence of metastatic lesions might explain the recurrence of ITP; however, FDG-PET scanning of the case showed no metastatic deposits anywhere in the body (fig. 2). Following intravenous immunoglobulin infusion (Ig VENA N I.V. ${ }^{\circledR}$, Onko, Istanbul, Turkey) at a
Fig. 1. Course of pre- and post-operative blood platelet levels.

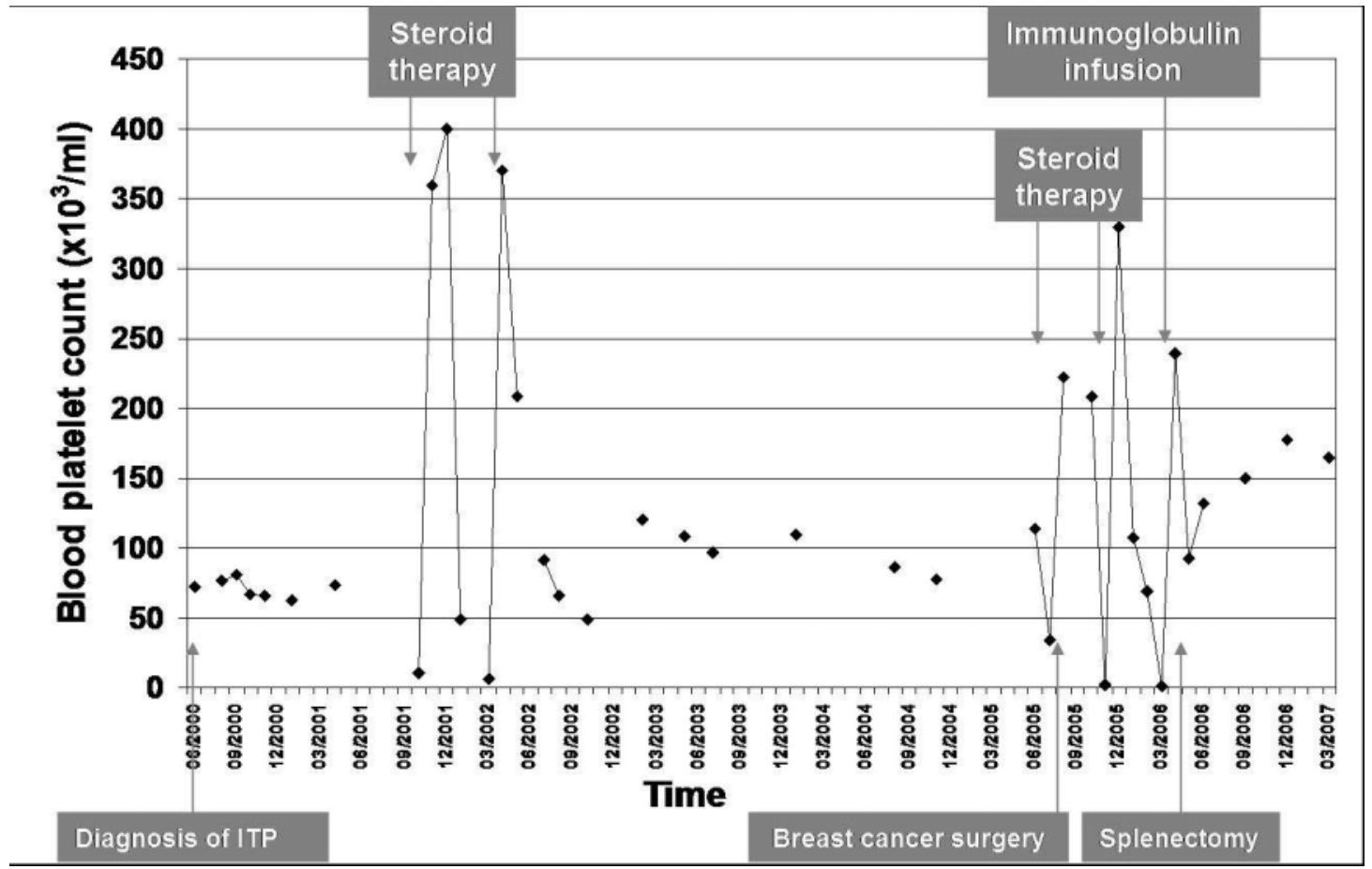

Gencosmanoglu/Unalan/Kir/Inceoglu 




Fig. 2. FDG-PET scan following breast cancer surgery did not show any metastatic deposits anywhere in the body.

dose of $1 \mathrm{~g} / \mathrm{kg} / \mathrm{day}$ for 2 days, the platelet count increased enough for surgery $(239,000 / \mathrm{ml})$, and the patient underwent splenectomy for ITP in the 10th month after breast cancer surgery. The postoperative period was uneventful. She has been symptom-free during the 1-year of follow-up with normal platelet levels.

\section{Discussion}

In cases of breast cancer associated with ITP, the appearance of ITP in the course of breast cancer has been variable. In some patients, ITP manifests itself simultaneously with the initial presentation of breast cancer [5]. In others, ITP occurs in the follow-up period after breast cancer surgery [6, 7]. In contrast, ITP may appear before breast cancer is diagnosed, even years earlier as was the case in our patient [1]. Theoretically, the presence of a long period between the diagnoses of ITP and breast cancer does not preclude their relationship, because breast cancer, as many solid organ tumors, usually becomes detectable long after its initiation while symptoms of ITP occur earlier even if both diseases started in the same period of life.

The exact mechanism of development of ITP in breast cancer cases or the reverse is still unknown. ITP and breast cancer are common disorders in the general population. But the number of reported cases of concurrence in the literature is quite low. If there was an apparent causality between them, more frequent concurrence would be expected. In addition, thrombocytopenia during the course of each patient's breast cancer has diverse presentations, and the therapeutic responses of ITP in these cases are variable. Because of all these considerations, Ustun et al. [8] concluded that the association between breast cancer and ITP may be only a coincidence. The largest series in the current literature described by de Latour et al. [1], consisted of 10 patients with ITP and breast cancer who were diagnosed and treated at the same institution. The authors concluded that where there was a long time interval between the 2 diseases, they were completely independent. However, ITP occurred during the course of breast cancer with an obvious clinical and laboratory relationship in some patients of the series; therefore, this immunologic disorder was considered a direct manifestation of the neoplasm in those cases by the authors. Unless splenic metastasis or bone marrow infiltration by tumor cells is shown by radiological, scintigraphic or histopathologic examinations, the association between ITP and breast cancer should be considered coincidental. ITP may respond to steroid therapy before the diagnosis of breast cancer and during the follow-up period as we also observed in our case. On the other hand, curative surgery in early breast cancer does not prevent the relapse of ITP in the postoperative period. Accordingly, thrombocytopenia developed once again in the postoperative period in the present case which eventually necessitated splenectomy.

Splenic metastasis from breast cancer is discussed as one of the mechanisms which may be responsible for the development of ITP during the course of the disease. Of the 18 previously reported cases, however, only 2 patients had splenic metastasis from breast cancer [9]. On the other hand, bone marrow metastasis was present in 7 of the 18 cases $(39 \%)$ [1, 3 , $6,9,10]$. Immune-mediated platelet destruction and presence of serum platelet agglutinins which may be shown by radioimmune and release antibody assays in solid tumors associated with ITP, including gynecologic malignant tumors and different types of lung cancers, are the other possible reasons [10]. Because the detection of anti-platelet antibodies is not considered to be an absolute diagnostic criterion for ITP, this 
test was not performed in our case [1]. Theoretically, antigenic characteristics of tumor cells may develop a cross reaction to platelets, or a currently unknown immunologic factor which might be released from cancer cells may affect platelets, and eventually these events may result in the destruction or consumption of platelets. However, a specific immunologic test that can prove such mechanisms has not yet been developed.

Finally, the histological type of the breast cancer may be speculated as a relevant factor in association with ITP. In the present case, it was an invasive ductal carcinoma, which is in accordance with the hypothesis by de Latour et al. [1] that the invasive ductal histological form of breast cancer is more frequently associated with ITP. Contrary to their observation that a positive hormonal receptor status is more prone to having accompanying ITP, the progesterone receptors were negative with mild estrogen receptor positivity in the present case. However, the relationship with the erbB-2 status, which was also negative in our patient, is still uncertain.

In conclusion, the relevant current data are conflicting on the relationship between ITP and breast cancer. The exact pathogenesis of this co-existence will be understood when more detailed data on such cases become available in the literature. The need of a specific immunologic test that shows particular antibodies against tumor cell antigens or a certain factor released by tumor causing platelet destruction for the identification of this association is indisputable.

\section{References}

1 Peffault de Latour R, Des Guetz G, Laurence V, Palangie T, Pierga JY, Dieras V, Jouve M, Extra JM, Pouillart P, Decaudin D: Breast cancer associated with idiopathic thrombocytopenic purpura: a single center series of 10 cases. Am J Clin Oncol 2004:27:333-336.

2 Fink K, Al-Mondhiry H: Idiopathic thrombocytopenic purpura in lymphoma. Cancer 1976;37: 1999-2004.

3 Berchtold P, McMillan R: Therapy of chronic idiopathic thrombocytopenic purpura in adults. Blood 1989;74:2309-2317.

4 Pass HA: Benign and malignant diseases of the breast; in Norton JA, Bollinger RR, Chang AE, Lowry SF, Mulvihill SJ, Pass HI, Thompson RW (eds): Surgery: Basic Science and Clinical Evidence. New York, Springer-Verlag, 2001, pp. 1699-1732.
Wahid FS, Fun LC, Keng CS, Ismail F: Breast carcinoma presenting as immune thrombocytopenic purpura. Int J Hematol 2001;73:399-400.

6 Porrata LF, Alberts S, Hook C, Hanson CA: Idiopathic thrombocytopenic purpura associated with breast cancer: a case report and review of the literature. Am J Clin Oncol 1999;22:411-413.

7 Igarashi T, Itoh K, Fujii H, Ohtsu T, Minami H, Sasaki Y, Shimizu W, Ogino T, Muramatsu M: Successful treatment by radiation and hormone therapy of isolated local recurrence of breast cancer 24 years after mastectomy accompanied by immune thrombocytopenia: a case report. Jpn J Clin Oncol 1998;28:270-275.

8 Ustun C, Dainer P, Hendricks L, Bruker CT, Burgess R: Association of breast cancer and immune thrombocytopenic purpura. South Med J 2002;95:1335-1337.
9 Cummings OW, Mazur MT: Breast carcinoma diffusely metastatic to the spleen. A report of two cases presenting as idiopathic thrombocytopenic purpura. Am J Clin Pathol 1992;97:484-489.

10 Schwartz KA, Slichter SJ, Harker LA: Immunemediated platelet destruction and thrombocytopenia in patients with solid tumours. Br J Haemato 1982;51:17-24. 